\title{
The Obstacles of Implementing Local Regulation No. 7 in 2010 about Green Space Arrangement at East Semaang Sub-District
}

\author{
Kidung Sukma Dewi; Dyah Lituhayu \\ Public Administration Doctoral Program, Faculty of Social and Political Science \\ Diponegoro University \\ Semarang, Indonesia \\ (Office email: prodidap@gmail.com)
}

\begin{abstract}
Green spaces are really needed in urban areas as society activities places. Green space is also one of key components in the construction of city infrastructure. The importance of green space in urban areas demanding the Government or private parties in order to fulfill the green space necessities. But often many obstacles that occur in the fulfillment of Green spaces in urban areas. The implementation of Local Regulation No.7 in 2010 about Structuring green space still experiencing barriers that arise from Government, private parties as well as societies. This research uses qualitative descriptive methods of gathering techniques data analysis through observation, interview and study documents.
\end{abstract}

Keywords-Green Space; Implementation; Local Regulation

\section{INTRODUCTION}

Urban development often results in any change over the land function. Existing green spaces are built into the building - a building is reducing green space. Whereas in the urban areas construction there is a critical component of green space. Green spaces needed for community activities. In addition green space on ecological functions as follow as an air refreshment, absorb rainwater, flood controlling, maintaining certain ecosystems, softener architecture buildings (Eco Budiharjo, 2009:91). Therefore this green space is very needed at urban areas because of the positive advantage. In fact, today the most urban areas in Indonesia hasn't implemented space organizing optimally, especially for green space arranging. The policy is issued as yet able to apply green space that is ideal for most cities - big cities in Indonesia. The natural environment is converted into the built environment without considering the ecosystem rules (Nirwono Joga, 2011:87).

Local Regulatory number 7 in 2010 about Structuring green space is the regulation governing structuring of $n$ green space in Semarang city. The achievement of green space in Semarang city refer to Local Regulation number 7 in 2010 as follows, $47.533 \%$ of the total area. Although the regulation as legal basis fulfillment of green space in Semarang city is already there but there are still obstacles that arise in the implementation such regulations. Fulfillment of green space in Semarang city is still said to be less even though there are already regulations governing. In the implementation of local regulations numbers 7 in 2010 is still experiencing some barriers which resulted still a lack of green space achievement in Semarang city.

\section{THEORETICAL FrAMEWORK AND METHOD}

This research obstacle of implementing Local Regulation Number 7 in 2010 about green space arrangement uses qualitative descriptive method. The data gotten through this research is empirical data that have specific validation criteria. Then the data that is gotten from this research can be used to understand, resolve and problem anticipate (Sugiyono, 2014:3). The technique of data colleting in this research is observation, interviewing and document study.

\section{Result AND DisCUSSION}

Green space areas in Semarang city recently reached $8510.48 \mathrm{Ha}$ or amounting to 23\% (Interpretation RTH 2015, DTK Semarang) is a green space areas, it can be seen that there is nothing green space in Semarang city, that means still not being met accordance with the Local Regulations number 7 in 2010 , as follow of $47.533 \%$ which is later divided into $34.204 \%$ of the total area is public and green space reach $13.329 \%$. This research choses locus in East Semarang as green space recently reached $6.30 \%$. From the interviews that have been conducted in East Semarang green space indeed has not met the targets should be achieved, but this Sub-district has made efforts to contribute fulfillment of green space in Semarang city particular in East Semarang. Each year the subdistrict parties always apply for assistance to the Department of agriculture tree seedlings which is later distributed to wards subdistricts of East Semarang to be planted and increasing the open green space areas.

However, in the implementation fulfillment of open green space in East Semarang apparently experiencing obstacles/barriers, namely because the area of East Semarang that sub-district indeed prone to flood make some quick crops damaged or even die before could grow larger. Besides greening through planting trees there is also the Park creation in East Semarang as one form fulfilment of green space. In 
district of East Semarang, there are several grounds - a large park that also often utilized community to conduct its activities. Some of it is used as a playground for children, a gathering place for societies to establish socialization, There are also grounds for elderly do gymnastics activities. In addition to the garden - large garden there is also a garden - a small garden in every sub-district. Maintenance of garden - a small garden becomes the responsibility of the districts parties and communities. While the garden - there is a large garden in East Semarang development and its maintenance is the responsibility of the Department of hygiene and city landscaping. One of them, namely rejomulyo garden, rejomulyo Park is a large park located in East Semarang where development and its maintenance is the responsibility of the Department of hygiene and city landscaping.

The condition of rejomulyo Park is still of concern, according to the sub-district that garden is not maintained by societies. In the development of children's rejomulyo encounter some obstacles/barriers that lead to the garden awoke recently achieved $0.5 \mathrm{Ha}$. The obstacles/constraints experienced by the Department of hygiene and Semarang city Landscaper in the development of children's rejomulyo because rejomulyo Park is once a market, and there is still an active market is making about children's rejomulyo serve as parking and loading and unloading goods to the market. Rejomulyo park is poultry market that have been relocated, In addition the market existence that's still active around obstacles/barriers experienced in the Park construction is assured the Department - Department related such that the place is worth to the public garden built, with a wide range of debate that occurs then the former poultry market Charter built a public park. Many questions arise why a garden that looks like rejomulyo are not cared for by the service of cleanliness and Landscaping Semarang city? It is actually not true, according to Mr. Budi as the Head Landscaper informing him that his staff always do every day watering the plants in each garden the garden existence in Semarang city include Rejomulyo park. Why look like is not treated?

Take a look at the conditions surrounding the park that looks like a slum, it is settlement that makes rejomulyo park look like not treated. In the development of children's rejomulyo park bases on Mr. Budi states have been doing planning by working closely with the Department of city planning and housing of Semarang city to tackle slums around the rejomulyo park. According to him, when such settlement has been restored or at relocation then construction of children's rejomulyo park can be performed optimally. The construction of rejomulyo Park is not far from the conflict anyway but back again with how parties - relate parties responding to and addressing him. Aside from the districts and service, the societies are one of the major components to support the development and maintenance of the grounds or public green space that exists in East Semarang district, the absence of power support from public then green space maintenance is still less and optimal. Public awareness is necessary in order to maintain the public green spaces, because the green space with regard to created necessities of an green space for societies. From the discussion above it can be seen that there are still some constraints/obstacles faced in the implementation of the Change number 7 in 2010 about the green space setup. It also resulted in a lack of green spaces are still public and private green space that exists in Semarang city (Interview with the Sub on February 1, 1999, interview with Mr. Budi head Landscaper on February 19, 2016). This study is conducted an implementation evaluation of the green space arrangement in East Semarang.

As for evaluation carried out using criteria according to William Dunn, namely effectiveness, efficiency, sufficiency, alignment, responsiveness, and precision (in the Riant Nugroho, 2006:155-256). In effectiveness and efficiency terms has been made an effort for green space fulfillment in East Semarang. The creation and park maintenance and tree planting is an effort that has been done by the Government and the public supportting green space. In adequacy terms, the Government has built a park in each subdistrict as a realization of the Government program. In alignment terms has been achieved is assessed from the Park construction in every sub-district have been done despite the maximum has not yet equitable development parks in every sub-district done by the Government. In responsiveness terms, the benefits of which have been felt by the green space existence in East Semarang, some children have been exploited by people with used as societies center, but there are grounds which can not be utilized or might not have been feasible to utilized by societies. The latter in accuracy terms, the Government purpose of green space fulfillment in Semarang city have yet to be achieved optimally, since the target is far from being written Local Regulation Number. 7 in 2010 about green space setup.

\section{CONCLUSION}

Green space in Semarang city is still not reaching the target bases on article written in Local Regulation in number 7 in 2010 about the setup of green space. That is because the existence of some constraints/obstacles in the implementation process of Regulatory region number 7 in 2010. Obstacles/barriers also resulted in the recent achievement of green space in East Semarang. Numerous attempts have been made to greening in Semarang city especially in East of Semarang. In keeping the Park -there should involve societies in order that they also realize that the Park is also theirs does not belong to the Government only. The City Government and private parties as well as the Sub-district of East Semarang party and societies should have a meeting to talk about planning and offer solutions on the development of children's rejomulyo park with do not cause harm surrounding societies.

\section{REFERENCES}

[1] Budiharjo, Eko, Djoko Sujarto. 2009.Kota Berkelanjutan (Sustainable City). Bandung: P.T.ALUMNI

[2] Dewi, Kidung Sukma. 2016.Evaluasi Pelaksanaan Penataan Ruang Terbuka Hijau di Kecamatan Semarang Timur. Skripsi: Universitas Diponegoro

[3] Interpretasi RTH Kota Semarang Tahun 2015

[4] Joga, Nirwono, Iwan Ismaun. 2011. Rth 30\%! Resolusi (Kota) Hijau. Jakarta: PT Gramedia

[5] Nugroho, Riant. (2006). Kebijakan Publik untuk Negara-Negara Berkembang. Jakarta: PT Gramedia. 
[6] Peraturan Daerah Kota Semarang Nomor 7 Tahun 2010 tentang Penataan Ruang Terbuka Hijau

[7] Sugiyono. 2014.Metode Penelitian Kuantitatif, Kualitatif dan R\&D.

Bandung: Alfabeta 